\title{
Returning to the accompaniment at the end of life as an important nursing care in palliative care
}

\section{Mini review}

The concept of dying has changed through the centuries. The different paradigms of knowledge, have influenced the culture, the science.....etc, as well as having influenced how to live, how to die and about end of life care.

Analyzing the historical evolution of the concept of "accompaniment at the end of life" it becomes evident that many different models exist. The oldest one is known as "The domestic death" or more commonly "The good death". In this case, people died at home, and the protagonist was the dying person. The death happened next to the family who took part through direction from the dying person.

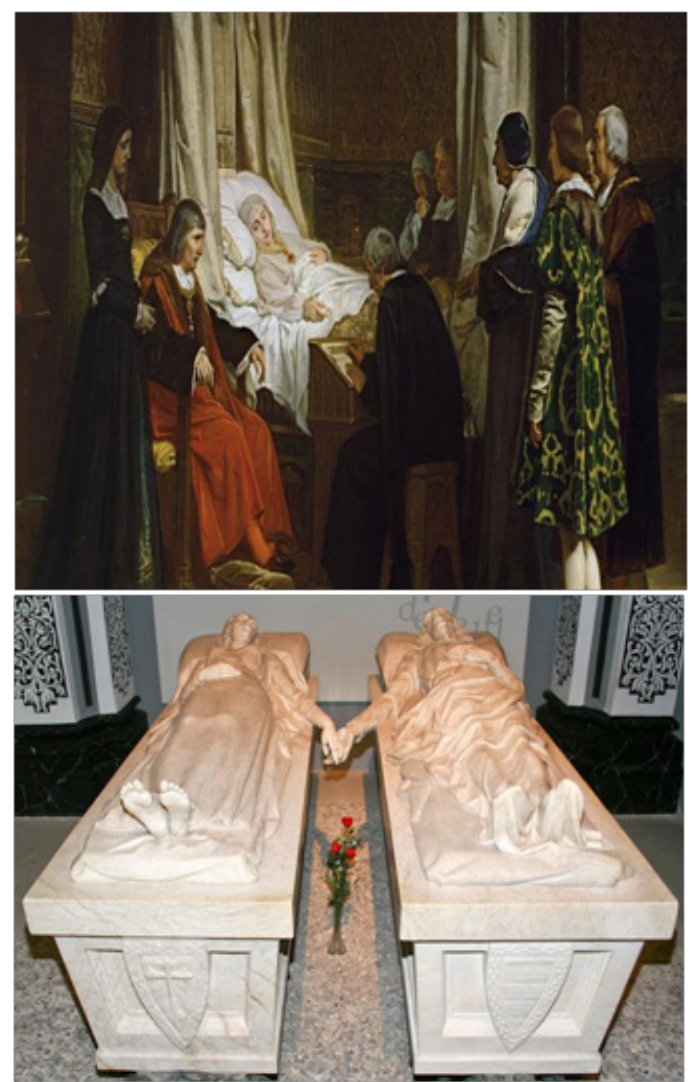

Between the $12^{\text {th }}-20^{\text {th }}$ centuries, death as a concept started to acquire a social importance, becoming somewhat of a social ritual This experience started to become separate from the traditional home and family setting; and instead moved the experience out of homes. Two different stages exist in this process. Firstly, in the Middle Ages, it was called "The one death" which was influenced by concepts like the Last judgement, purgatory...e.g.

The Romantic Movement, in the $18^{\text {th }}$ century, gets a short conciliation with death even seeing the beauty of its own.
Volume 3 Issue I - 2019

Inmaculada Minguez Moreno

Department of Nursing, University of Alicante, Spain

Correspondence: Inmaculada Minguez Moreno, PhD student, Department of Nursing, University of Alicante, Zaragoza (Spain), Email rodiles78@hotmail.com

Received: April 08, 2018 | Published: January 02, 2019

In the $19^{\text {th }}$ century stars the second stage, which can be called "Of the others death" "taking relevance in society and being manifested with the cult in cemeteries, exaggerated mourning...

In the $20^{\text {th }}$ century, after the Second World War, began another stage, which can be called "the forbidden death" or "the technologic death". ${ }^{1}$ In this stage, death is understood separate of life, society and as a medical failure. People die alone in the hospitals far away from their families and homes. It is considered as a non-natural phenomenon.



With the becoming of the $20^{\text {th }}$ century the paradigms of knowledge started to change. These changes to the concept of dying came in the second half of the century to medicine and nursing, approaching the traditional model which brought new areas of care, like palliative care. Thus allowing death to occupy another time as a part of it..$^{2-4}$ This creates a challenge for the nurse who is one of the most essential supports in care during end of life. One of the most important aspects of care is accompaniment for the dying person in order to ensure they experience a worthy death as well as ensuring the families have space for the critical mourning period. The Michigan In service Education Council state in their declaration for the persons who are in the end of life, that: I have the right to not die alone. 


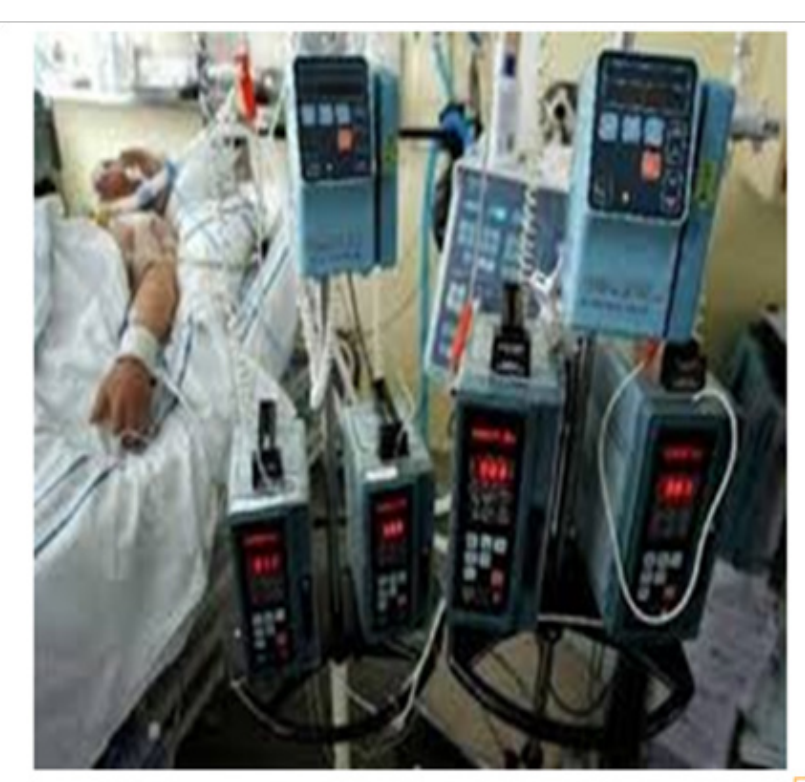

This should remain essential to nursing as an important role when being trained, to ensure clear and effective care, as well as an important professional responsibility when assisting people to experience a worthy death and accept death as part of life.

\section{Acknowledgments}

None.

\section{Conflicts of interest}

The authors declare there is no conflicts of interest.

\section{References}

1. https://rua.ua.es/dspace/bitstream/10045/963/1/culturacuidados_19_03. pdf

2. Peña Tejeiro E de la, Herrero Olea A, Gómez Galán R, et al. Ayudar a morir un reto para el enfermero/a. Enferm Cient. 2001;(226-227):5-6

3. Lopera-Betancur MA. The importance attributed by nurses to training in the care of terminal patients. Enfermería universitaria. 2015;12(2):7379 .

4. Morin E. El método. La humanidad de la humanidad. La identidad humana. Madrid: Ediciones Cátedra; 2003:342. 